\title{
Role of Projections from Ventral Medial Prefrontal Cortex to Nucleus Accumbens Shell in Context-Induced Reinstatement of Heroin Seeking
}

\author{
Jennifer M. Bossert, ${ }^{1}$ Anna L. Stern, ${ }^{1}$ Florence R. M. Theberge, ${ }^{1}$ Nathan J. Marchant, ${ }^{1}$ Hui-Ling Wang, ${ }^{2}$ \\ Marisela Morales, ${ }^{2}$ and Yavin Shaham ${ }^{1}$ \\ ${ }^{1}$ Behavioral Neuroscience Branch and ${ }^{2}$ Cellular Neurobiology Research Branch, Intramural Research Program, National Institute on Drug Abuse, National \\ Institutes of Health/Department of Health and Human Services, Baltimore, Maryland 21224
}

In humans, exposure to contexts previously associated with heroin use can provoke relapse. In rats, exposure to heroin-paired contexts after extinction of drug-reinforced responding in different contexts reinstates heroin seeking. This effect is attenuated by inhibition of glutamate or dopamine transmission in nucleus accumbens shell, or inactivation of ventral medial prefrontal cortex (mPFC). Here, we used an anatomical asymmetrical disconnection procedure to demonstrate that an interaction between glutamatergic projections from ventral $\mathrm{mPFC}$ to accumbens shell and local dopamine $\mathrm{D}_{1}$ postsynaptic receptors contributes to context-induced reinstatement of heroin seeking. We also combined the marker of neuronal activity, Fos, with the retrograde tracer Fluoro-Gold to assess activation in this pathway during context-induced reinstatement. Rats were trained to self-administer heroin for $12 \mathrm{~d}$; drug infusions were paired with a discrete tone-light cue. Lever pressing was subsequently extinguished in a nondrug-associated context in the presence of the discrete cue. Rats were then tested in the heroin- or extinction-associated contexts under extinction conditions. Injections of muscimol + baclofen into ventral mPFC in one hemisphere and $\mathrm{D}_{1}$-family receptor antagonist $\mathrm{SCH} 23390$ into the contralateral or ipsilateral accumbens shell decreased context-induced reinstatement. Unilateral injections of muscimol + baclofen into ventral mPFC or SCH 23390 into the accumbens shell had no effect. Context-induced reinstatement was associated with increased Fos expression in ventral mPFC neurons, including those projecting to accumbens shell, with higher double-labeling in the ipsilateral projection than in the contralateral projection. Our results demonstrate that activation of glutamatergic projections from ventral mPFC to accumbens shell, previously implicated in inhibition of cocaine relapse, promotes heroin relapse.

\section{Introduction}

Exposure to environmental contexts associated with heroin intake can provoke drug relapse in humans (Wikler, 1973; O'Brien et al., 1992). We adapted an ABA renewal procedure (Bouton and Bolles, 1979) to study the role of drug-associated contexts in drug seeking (Crombag and Shaham, 2002). Using this procedure, we and others have found that re-exposing rats to drug-associated contexts after extinction of drug-reinforced responding in different contexts reinstates heroin seeking (Bossert et al., 2004), cocaine seeking (Fuchs et al., 2005), alcohol seeking (Zironi et al.,

Received Jan. 2, 2012; revised Feb. 17, 2012; accepted Feb. 22, 2012

Author contributions: J.M.B., H.W., M.M., and Y.S. designed research; J.M.B., A.S., F.R.M.T., and H.W. performed research; J.M.B., A.S., and N.J.M. analyzed data; J.M.B., A.S., N.J.M., and Y.S. wrote the paper.

This work was supported by the Intramural Research Program of the National Institute on Drug Abuse (NIH, DHHS). We thank Brittany Navarre, Carlo Cifani, and Sanya Fanous for their help in conducting the experiments. We also thank Susan Sesack, Stan Floresco, Kue Tseng, Anthony Grace, Patricio O'Donnell, and Bita Moghaddam for helpful advice on anatomical and circuit issues discussed in this paper.

The authors declare that they do not have any conflicts of interest (financial or otherwise) related to the data presented in this manuscript.

Correspondence should be addressed to Jennifer M. Bossert, Behavioral Neuroscience Branch, Intramural Research Program/National Institute on Drug Abuse/National Institutes of Health, 251 Bayview Boulevard, Baltimore, MD 21224. E-mail: jbossert@intra.nida.nih.gov.

DOI:10.1523/JNEUROSCI.0005-12.2012

Copyright $\odot 2012$ the authors $\quad 0270-6474 / 12 / 324982-10 \$ 15.00 / 0$
2006; Hamlin et al., 2007), or nicotine seeking (Diergaarde et al., 2008).

We previously identified roles of dopamine and glutamate transmission in accumbens shell, but not in core, in contextinduced reinstatement of heroin seeking (Bossert et al., 2006a, 2007). We also found that context-induced reinstatement is attenuated by reversible inactivation of ventral medial prefrontal cortex (mPFC) (ventral part of prelimbic and infralimbic cortices) (Bossert et al., 2011), which sends glutamatergic projections to accumbens shell (Sesack et al., 1989; Groenewegen et al., 1999). Neuronal activity in accumbens shell is dependent on both glutamate and dopamine $\mathrm{D}_{1}$-receptor-mediated neurotransmission (O'Donnell, 2003), and there is evidence that cues that predict drug availability increase dopamine release in nucleus accumbens (Weiss et al., 2000). Thus, we hypothesized that synergistic activation of both dopamine $\mathrm{D}_{1}$ postsynaptic receptors and cortical glutamatergic projections is required for accumbens shell to mediate context-induced reinstatement of heroin seeking (Crombag et al., 2008). Here, we tested this hypothesis by using a variation of an anatomical asymmetrical disconnection procedure in which we inactivated ventral $\mathrm{MPFC}$ neurons in one hemisphere and blocked activation of dopamine $\mathrm{D}_{1}$-receptors in the accumbens shell of the contralateral hemisphere during context- 
induced reinstatement of heroin seeking. In the classic asymmetrical disconnection procedure, which was previously employed to study roles of neuronal pathways in drug seeking (Belin and Everitt, 2008; Peters et al., 2008; Millan et al., 2010) and other learned behaviors (Everitt et al., 1991; Floresco et al., 1997), unilateral manipulations, such as permanent or reversible lesions or receptor blockade, are made in contralateral or ipsilateral hemispheres of two different anatomically connected structures. The role of a putative serial neuronal pathway in a given behavior is then inferred when behavior is disrupted by the contralateral but not by ipsilateral manipulation (Gaffan et al., 1993; Setlow et al., 2002).

Surprisingly, both the contralateral and ipsilateral manipulations inhibited context-induced reinstatement, suggesting that both the dense ipsilateral and sparse contralateral glutamatergic projections from ventral mPFC to accumbens shell (Sesack et al., 1989) are activated during reinstatement. We tested this idea by combining the neuronal activity marker Fos (Sagar et al., 1988), to identify neurons activated by the heroin-associated context, with labeling accumbens shell-projecting ventral mPFC neurons via unilateral iontophoresis injections of the retrograde tracer Fluoro-Gold (FG) (Schmued and Fallon, 1986) into accumbens shell. Colocalization of FG with Fos was assessed in both ipsilateral and contralateral ventral mPFC after tests for context-induced reinstatement or extinction tests. We found that context-induced reinstatement was associated with Fos induction in FG-positive neurons that project to both ipsilateral accumbens shell and contralateral accumbens shell, which together with our neuropharmacological "disconnection" data, suggest that projections from ventral mPFC to accumbens shell contribute to context-induced reinstatement of heroin seeking.

\section{Materials and Methods}

Subjects. Male Long-Evans rats (Charles River) weighing 350-450 g were used. After surgery, the rats were housed individually in the animal facility under a reverse $12 \mathrm{~h}$ light/dark cycle (lights off at 8:00 A.M.). Food and water were freely available in the rats' home cages throughout the experiment. Experimental procedures followed the guidelines of the Principles of Laboratory Animal Care (NIH publication no. 86-23, 1996). Twentyseven rats were excluded due to misplaced cannulas $(n=5)$ or FG tracer deposit $(n=9)$ or by failure to meet an extinction criterion of a mean of less than 25 responses per $3 \mathrm{~h}$ over $3 \mathrm{~d}$ after 22 extinction sessions $(n=13)$.

Intracranial and intravenous surgery (Experiment 1 and Experiment 2). Rats were anesthetized with sodium pentobarbital and chloral hydrate (60 and $25 \mathrm{mg} / \mathrm{kg}$, i.p.), and permanent guide cannulas (23 gauge, Plastics One) were implanted unilaterally $1 \mathrm{~mm}$ above ventral mPFC and 1 $\mathrm{mm}$ above medial accumbens shell in the ipsilateral or contralateral hemisphere. We used stereotaxic coordinates (Paxinos and Watson, 2005) based on our previous work and that of others (Ikemoto et al., 2005; Bossert et al., 2007; Rogers et al., 2008; Koya et al., 2009a). The coordinates (nose bar set at $-3.3 \mathrm{~mm}$ ) for ventral mPFC were anteroposterior $(\mathrm{AP})+3.0 \mathrm{~mm}$, mediolateral $(\mathrm{ML}) \pm 1.5 \mathrm{~mm}\left(10^{\circ}\right.$ angle $)$, and dorsoventral (DV) $-4.3 \mathrm{~mm}$; for contralateral accumbens shell the coordinates were $\mathrm{AP}+1.7 \mathrm{~mm}, \mathrm{ML} \pm 3.8 \mathrm{~mm}\left(25^{\circ}\right.$ angle $)$, and $\mathrm{DV}-6.8$ $\mathrm{mm}$; and for ipsilateral accumbens shell the coordinates were AP +1.7 $\mathrm{mm}, \mathrm{ML} \pm 1.6 \mathrm{~mm}\left(20^{\circ}\right.$ angle $)$, and $\mathrm{DV}-7.2 \mathrm{~mm}$. Because of stereotaxic constraints, cannulas for ipsilateral medial accumbens shell were inserted at a $20^{\circ}$ angle from the contralateral hemisphere through the midline (Ikemoto et al., 2005). Following cannula implantation, silastic catheters were inserted into the jugular vein as described previously (Bossert et al., 2004, 2006a; Lu et al., 2004). Catheters were attached to a modified 22 gauge cannula and mounted to the rat's skull with dental cement. Buprenorphine $(0.1 \mathrm{mg} / \mathrm{kg}$, s.c.) was given after surgery to relieve pain, and rats were allowed to recover for 7-10 d before heroin self-administration training. During the recovery and training phases, catheters were flushed every 24-48 h with gentamicin (Butler Schein, $5 \mathrm{mg} / \mathrm{ml}$ ) and sterile saline. At the end of Experiment 1 and Experiment 2, the rats were deeply anesthetized, decapitated, and their brains were removed for verification of cannula placements. In Experiment 3, the rats were perfused after anesthesia as described below in Double labeling Fos-FG immunohistochemistry.

Iontophoresis of retrograde tracer and intravenous surgery (Experiment 3). Rats underwent i.v. catheterization surgery before heroin selfadministration training and underwent retrograde tracer surgery between training and the start of the extinction phase. For i.v. catheterization, rats were anesthetized, catheterized, and recovered as described above, with the exception that catheters were attached to a modified 22 gauge cannula cemented to polypropylene mesh (Small Parts Inc.) and fixed in the mid-scapular region. For the tracer surgery, rats were anesthetized as described above and secured in a stereotaxic apparatus. The FG injection procedure was based on previous work from the Morales laboratory (Morales and Wang, 2002; Yamaguchi et al., 2011). FG (1\% in cacodylate buffer, pH 7.5) (Schmued and Fallon, 1986; Divac and Mogensen, 1990) was delivered iontophoretically unilaterally into medial accumbens shell $\left[\mathrm{AP}+1.7 \mathrm{~mm}, \mathrm{ML} \pm 2.0 \mathrm{~mm}\left(10^{\circ}\right.\right.$ angle $)$, DV $-7.5 \mathrm{~mm}$ ] through a stereotaxically positioned glass micropipette (inner tip diameter $50 \mu \mathrm{m}$ ) by applying $4 \mu \mathrm{A}$ current in $5 \mathrm{~s}$ on/off pulses for $20 \mathrm{~min}$. The micropipette was left in place for an additional $5 \mathrm{~min}$ to prevent backflow of tracer up the injection track, and iontophoresis into left or right hemisphere was alternated. Rats were given 6-9 d of recovery before the extinction phase began (see below, Experiment 3 ).

Intracranial injections. SCH 23390 hydrochloride (Tocris, Ellisville, MO) and muscimol + baclofen (Tocris Bioscience) were dissolved in sterile saline and injected 5-10 min before testing. Doses of SCH 23390 hydrochloride $(1.85 \mathrm{nmol} / 0.5 \mu \mathrm{l} / \mathrm{side})$ and muscimol $(0.03 \mathrm{nmol} / 0.5$ $\mu \mathrm{l} /$ side $)+$ baclofen $(0.3 \mathrm{nmol} / 0.5 \mu \mathrm{l} /$ side $)$ were based on previous studies (McFarland and Kalivas, 2001; Bossert et al., 2007; Rogers et al., 2008; Koya et al., 2009b). Intracranial injections were made using a syringe pump (Harvard Apparatus) connected to $10 \mu \mathrm{l}$ Hamilton syringes that were attached via polyethylene-50 tubing to 30 gauge injectors. $\mathrm{SCH}$ 23390, muscimol + baclofen, and vehicle (saline) injections were made over $1 \mathrm{~min}$, and the injectors were left in place for $1 \mathrm{~min}$. After testing, the rats were deeply anesthetized, decapitated, and brains were removed and stored in $10 \%$ formalin before sectioning. Using a cryostat (Leica Microsystems), the brains were sectioned in the coronal plane $(50 \mu \mathrm{m})$, mounted on gelatin-coated slides, and stained with Cresyl Violet. Brains were then verified for cannula placement under a light microscope.

Double labeling Fos-FG immunohistochemistry. The Fos, FG, and Fos + FG immunohistochemistry procedures are based on previous reports (Morales et al., 1998; Morales and Wang, 2002; Shalev et al., 2003; Miller and Marshall, 2005; Bossert et al., 2011; Yamaguchi et al., 2011). We also performed extensive pilot studies to optimize the conditions for the FG + Fos double-labeling assay to eliminate nonspecific labeling and crossreactivity between the different antibodies, using established criteria from the Morales laboratory.

Ninety minutes after exposure to Context A or Context B, rats were deeply anesthetized with isoflurane $(\sim 80 \mathrm{~s})$ and perfused transcardially with $100 \mathrm{ml}$ of $0.1 \mathrm{M}$ PBS followed by $400 \mathrm{ml}$ of $4 \%$ paraformaldehyde in $0.1 \mathrm{~m}$ sodium phosphate, $\mathrm{pH}$ 7.4. Brains were removed and postfixed in $4 \%$ paraformaldehyde for $2 \mathrm{~h}$ before transfer to $20 \%$ sucrose in $0.1 \mathrm{M}$ sodium phosphate, $\mathrm{pH} 7.4$, for $48 \mathrm{~h}$ at $4^{\circ} \mathrm{C}$. Brains were subsequently frozen in powdered dry ice and stored at $-80^{\circ} \mathrm{C}$ until sectioning. Coronal sections $(20 \mu \mathrm{m})$ containing $\mathrm{mPFC}$ and medial accumbens shell (approximately +2.5 to $+3.7 \mathrm{~mm}$ and +1.2 to $+2.2 \mathrm{~mm}$ from bregma, respectively) were cut using a cryostat, collected in cryoprotectant $(20 \%$ glycerol and 2\% DMSO in $0.1 \mathrm{~m}$ sodium phosphate, $\mathrm{pH} 7.4$ ), and stored at $-80^{\circ} \mathrm{C}$ until further processing.

Free-floating sections were rinsed (three times for 10 min each) in PBS, incubated for $1 \mathrm{~h}$ in 3\% normal goat serum (NGS) in PBS with $0.25 \%$ Triton $\mathrm{X}-100$ (PBS-Tx), and incubated overnight at $4^{\circ} \mathrm{C}$ with rabbit anti-c-Fos primary antibody (c-Fos sc-52, Lot I0309, Santa Cruz Biotechnology) diluted 1:4000 in 3\% NGS in PBS-Tx. The sc-52 antibody was raised against amino acids 3-16 of human c-Fos: SGFNADYEASSSRC. Sections were then rinsed in PBS and incubated for $2 \mathrm{~h}$ with biotinylated anti-rabbit IgG secondary antibody (BA-1000, Vector Laboratories) 
diluted 1:600 in 1\% NGS in 0.25\% PBS-Tx. Sections were again rinsed in PBS and incubated in avidin-biotin-peroxidase complex (ABC; ABC Elite kit, PK-6100, Vector Laboratories) in 0.5\% PBS-Tx for $1 \mathrm{~h}$. Sections were then rinsed in PBS and developed in Vector SG (blue/ gray product; Vector SG peroxidase substrate kit, Vector Laboratories). This reaction was terminated by rinsing the tissue in $0.1 \mathrm{M}$ Tris. Sections were rinsed several times, incubated in $0.3 \% \mathrm{H}_{2} \mathrm{O}_{2}$ for 30 min, and then rinsed before incubation for $1 \mathrm{~h}$ in $0.3 \%$ PBS-Tx containing $4 \%$ bovine serum albumin (BSA) and avidin D (avidin-biotin blocking kit; Vector Laboratories). Sections were then incubated overnight at $4^{\circ} \mathrm{C}$ with rabbit anti-FG primary antibody (AB153; anti-Fluorescent Gold, Millipore) diluted 1:15,000 in 4\% BSA, 0.3\% PBS-Tx, and biotin. Sections were then rinsed in PBS and incubated for $1 \mathrm{~h}$ with biotinylated anti-rabbit IgG secondary antibody (BA-1000, Vector Laboratories) diluted 1:200 in 4\% BSA in 0.3\% PBS-Tx. Sections were again rinsed in PBS and incubated in $\mathrm{ABC}$ in $\mathrm{PBS}$ for $1 \mathrm{~h}$. Sections were then rinsed in PBS and developed in $3,3^{\prime}$-diaminobenzidine (DAB), rinsed in PBS, mounted onto chrome alum/ gelatin-coated slides, and air dried. Slides were dehydrated through a graded series of alcohol concentrations (30, 60, 90, 95, 100, 100\% ethanol), cleared with Citrasolv (Fisher Scientific), and coverslipped with Permount (Fisher Scientific).

Because the primary antibodies against c-Fos and FG were raised in rabbit, we tested for a possible cross-reactivity of between the secondary antibody used to label FG with bound c-Fos primary antiserum (Miller and Marshall, 2005). Some sections were processed for dual detection of c-Fos (Vector SG) and FG (DAB) and either the FG primary or secondary antibodies were omitted. Omission of either FG primary or secondary antibodies produced no anomalous additional labeling that could be interpreted as Fos (data not shown).

We also performed an assay in which we used goat anti-c-Fos primary antibody. Free-floating sections were rinsed (three times for $10 \mathrm{~min}$ each) in PBS, incubated in $0.3 \%$ hydrogen peroxide $\left(\mathrm{H}_{2} \mathrm{O}_{2}\right)$ for $30 \mathrm{~min}$, rinsed three more times in PBS, and incubated for $1 \mathrm{~h}$ in blocking buffer $4 \%$ BSA in PBS with $0.3 \%$ Triton X-100. Sections were then incubated overnight at $4^{\circ} \mathrm{C}$ with rabbit anti-FG primary antibody $(\mathrm{AB} 153$; anti-Fluorescent Gold, Millipore) diluted 1:4000 in blocking buffer. Sections were then rinsed in PBS and incubated for $2 \mathrm{~h}$ with peroxidase-conjugated donkey anti-rabbit secondary antibody (Jackson ImmunoResearch Laboratories) diluted 1:500 in blocking buffer. Sections were rinsed and the peroxidase reaction was developed in DAB. Sections were rinsed several times, incubated in $0.3 \% \mathrm{H}_{2} \mathrm{O}_{2}$ for $30 \mathrm{~min}$, rinsed three more times, incubated for $1 \mathrm{~h}$ in blocking buffer, and then incubated overnight at $4^{\circ} \mathrm{C}$ with goat anti-c-Fos primary antibody (c-Fos sc-52-G, Santa Cruz Biotechnology) diluted 1:500 in blocking buffer. Sections were rinsed in PBS and incubated for $2 \mathrm{~h}$ with biotinylated horse anti-goat secondary antibody (BA-9500, Vector Laboratories) diluted 1:500 in blocking buffer. Sections were then rinsed and incubated for $1 \mathrm{~h}$ in $\mathrm{ABC}$ (PK-4000, Vector Laboratories) in $0.5 \%$ PBS-Tx. Sections were then rinsed in PBS and developed with an SG peroxidase substrate kit (blue/gray product; SK4700 , Vector Laboratories). Sections were rinsed several times in PBS, mounted onto chrome alum/gelatin-coated slides, and air dried. Slides were dehydrated, cleared, and coverslipped as described above.

Because the number of Fos-immunoreactive (IR)-positive nuclei per $\mathrm{mm}^{2}$ with the goat anti-c-Fos antibody was significantly lower than that of the rabbit c-Fos antibody in the assay described above [see data in Table 1 (goat c-Fos antibody) versus Fig. 4 (rabbit c-Fos antibody)] and in our previous report (Bossert et al., 2011), we also tested for differences between the two antibodies in a single-labeled Fos-IR assay using ventral $\mathrm{mPFC}$ of a rat injected with yohimbine $(2 \mathrm{mg} / \mathrm{kg}$, i.p), which causes strong Fos expression in this brain area (Nair et al., 2011). We found that Fos-IR detected using the goat anti-c-Fos antibody ( 136 counts $/ \mathrm{mm}^{2}$ ) was about $60 \%$ of the Fos-IR detected by the rabbit c-Fos antibody (216 counts $/ \mathrm{mm}^{2}$ ). The reasons for the lower Fos-IR expression with the goat c-Fos antibody are unknown, but because of this lower expression, we primarily report data from results with the rabbit anti-c-Fos antibody.

Brightfield images of immunoreactive cells in ventral $\mathrm{mPFC}$ were digitally captured using an EXi Aqua camera (QImaging) attached to a Zeiss Axio Scope 2, Axio Imager M2, or an Olympus BX51 microscope. The goal was to compare the number of Fos-IR, FG-IR, and double-labeled cells in ventral mPFC in both the ipsilateral and contralateral hemispheres to the FG deposit. FG-IR cells were identified by a brown product in the cytoplasm, Fos-IR cells were identified by a dark blue reaction product in the nuclei, and double-labeled cells were identified by a dark blue nucleus surrounded by brown cytoplasm. For each rat, cells were quantified in two hemispheres of three sections (three ipsilateral counts and three contralateral counts) and the counts were averaged to give a mean number of each immunoreactive cell type per area. Images were captured and analyzed using IVision (4.0.15 and 4.5.0, Biovision Technologies) or Surveyor with Turboscan (Objective Imaging) software at $10 \times, 20 \times$, and $40 \times$ magnification. Image capture and quantification of cells were conducted in a blind manner.

Apparatus and procedures. The rats were trained and tested in standard Med Associates self-administration chambers. Each chamber was equipped with two levers located $9 \mathrm{~cm}$ above the grid floor. Lever presses on the active retractable lever activated the infusion pump, whereas lever presses on the inactive nonretractable lever had no programmed consequences. The two contexts differed from each other in terms of their auditory, visual, tactile, and circadian [i.e., morning (session onset at 9:00 A.M.) vs afternoon (session onset at 3:00 P.M.) sessions] cues, using procedures identical to those described in our previous studies (Bossert et al., 2006b, 2007, 2009). The contexts are referred to as A and B, where $\mathrm{A}$ is the heroin self-administration (training) and reinstatement (testing) context, and B is the extinction context. The physical environments of Contexts A and B and circadian cues were counterbalanced.

Procedures. The experiments consisted of three phases: selfadministration training (12 d), extinction training (14-22 d), and tests for context-induced reinstatement of heroin seeking ( 1 or $2 \mathrm{~d}$ ). The experimental sequence was Context A (training)—Context B (extinction)—Contexts A and B (testing).

Heroin self-administration training and extinction. Rats were trained to self-administer heroin for $3 \mathrm{~h} / \mathrm{d}$ for $12 \mathrm{~d}$. Heroin (diacetylmorphine $\mathrm{HCl}$; National Institute on Drug Abuse) was dissolved in sterile saline and infused at a volume of $65 \mu \mathrm{l}$ over $2.3 \mathrm{~s}$ at a dose of 0.1 (first six sessions) and 0.05 (last six sessions) $\mathrm{mg} / \mathrm{kg} /$ infusion. During training, heroin infusions were earned under a fixed-ratio-1 (FR1) $2.3 \mathrm{~s}$ timeout reinforcement schedule and were paired with a compound tone-light cue for $2.3 \mathrm{~s}$. During the extinction phase (Context B), responses on the previously active lever led to presentation of the tone-light cue but not heroin. Tests for context-induced reinstatement were conducted under extinction conditions (lever presses led to the presentation of the tone-light cue but not heroin) and began after a minimum of 14 daily extinction sessions when the rats met the extinction criterion of a mean of fewer than 25 presses on the previously active lever over the last three extinction sessions.

Experiment 1: effect of unilateral muscimol + baclofen injections into ventral mPFC and contralateral or ipsilateral SCH 23390 injections into medial accumbens shell on context-induced reinstatement. We used 34 rats that were divided into four groups $(n=6-11)$ using a 2 (drug condition: vehicle versus muscimol-baclofen $+\mathrm{SCH} 23390) \times 2$ (disconnection manipulation: ipsilateral versus contralateral injections) experimental design. The two vehicle groups were injected with saline into ventral mPFC of one hemisphere and medial accumbens shell of the same (ipsilateral) or other (contralateral) hemisphere. The drug groups were injected with muscimol + baclofen $(0.03+0.3 \mathrm{nmol} / 0.5 \mu \mathrm{l})$ into ventral mPFC of one hemisphere and SCH $23390(1.85 \mathrm{nmol} / 0.5 \mu \mathrm{l})$ into medial accumbens shell of ipsilateral or contralateral hemisphere. Each rat was tested twice with their assigned dose (vehicle or drug): once before exposure to Context A (heroin context) and once before exposure to Context $\mathrm{B}$ (extinction context). The tests were separated by $48 \mathrm{~h}$ and rats remained in the animal housing room between tests. Rats in the vehicle and drug groups were matched for their heroin intake and the number of active lever presses during training and extinction. The order of testing in Contexts A and B was counterbalanced, as was implantation of cannulas into either the left or right hemisphere in ventral mPFC and ipsilateral or contralateral medial accumbens shell. After testing, the rats were deeply anesthetized, decapitated, and their brains were removed.

To rule out the possibility that the effects of ipsilateral and contralateral drug injections in Experiment 1 are due to motor deficits, 8 rats were 
trained after the completion of Experiment 1 to lever-press for $45 \mathrm{mg}$ food pellets under an FR1 20 s timeout reinforcement schedule for twelve 30 min sessions. Subsequently, we assessed in two different sessions that were separated by $72 \mathrm{~h}$ the effect of vehicle injections into ventral mPFC and accumbens shell or muscimol-baclofen injections into ventral mPFC and SCH 23390 injections into ipsilateral or contralateral accumbens shell on food-reinforced responding. Test sessions were counterbalanced and rats were run in food self-administration sessions on days in between the tests.

Experiment 2: effect of unilateral muscimol + baclofen injections into ventral mPFC or unilateral SCH 23390 injections into medial accumbens shell on context-induced reinstatement. In Experiment 1, we found that both contralateral and, unexpectedly, ipsilateral injections of muscimol + baclofen or SCH 23390 into ventral mPFC or accumbens shell, respectively, decreased context-induced reinstatement of heroin seeking. The purpose of Experiment 2 was to rule out the possibility that these effects are merely due to independent unilateral interruption of neurotransmission in ventral $\mathrm{mPFC}$ or accumbens shell. We assessed this possibility by determining the effect of unilateral injection of muscimol + baclofen into ventral mPFC or unilateral injection of SCH 23390 into accumbens shell on context-induced reinstatement.

We used 20 rats divided into three groups $(n=6-7)$. The vehicle group was injected with saline into ventral $\mathrm{mPFC}$ of one hemisphere and accumbens shell of the ipsilateral or contralateral hemisphere. The muscimol + baclofen group was injected with muscimol + baclofen $(0.03+$ $0.3 \mathrm{nmol} / 0.5 \mu \mathrm{l}$ ) into ventral $\mathrm{mPFC}$ of one hemisphere and saline into accumbens shell of the ipsilateral or contralateral hemisphere. The SCH 23390 group was injected with SCH $23390(1.85 \mathrm{nmol} / 0.5 \mu \mathrm{l})$ into accumbens shell of one hemisphere and saline into ventral mPFC of ipsilateral or contralateral hemisphere. Each rat was tested twice with their assigned dose (vehicle, muscimol + baclofen in ventral mPFC, or SCH 23390 in accumbens shell): once before exposure to Context A (heroin context) and once before exposure to Context B (extinction context). The tests were separated by $48 \mathrm{~h}$, and rats remained in the animal housing room between tests. Rats in the vehicle and drug groups were matched for their heroin intake and number of active lever presses during training and extinction. The order of testing in Contexts A and B was counterbalanced, as well as implantation of the cannulas into either left or right hemisphere in ventral mPFC and ipsilateral or contralateral accumbens shell.

Experiment 3: unilateral iontophoresis of FG into accumbens shell and colocalization of $F G$ with Fos in ipsilateral and contralateral ventral mPFC after a context-induced reinstatement test. In Experiment 2, we found that unilateral injections of muscimol + baclofen or SCH 23390 into ventral mPFC or accumbens shell, respectively, had no effect on contextinduced reinstatement. Based on this finding, we assessed whether the similar effects of the contralateral and ipsilateral disconnection manipulations in Experiment 1 are due to activation of both ipsilateral and contralateral glutamatergic projections from ventral $\mathrm{mPFC}$ to accumbens shell (Sesack et al., 1989; Vertes, 2004).

We used eight rats that were divided into two groups $(n=4$ per group). The Control group (A-B-B) underwent heroin selfadministration training $(3 \mathrm{~h} / \mathrm{d})$ in Context $\mathrm{A}$ and extinction training (3 $\mathrm{h} / \mathrm{d}$ ) and reinstatement testing $(90 \mathrm{~min})$ in Context $\mathrm{B}$. The Renewal group (A-B-A) underwent heroin self-administration training in context $\mathrm{A}$, extinction training in context $\mathrm{B}$, and reinstatement testing in context A. The reinstatement test was $90 \mathrm{~min}$ because of the known time course of Fos induction after exposure to drug or nondrug stimuli (Curran and Morgan, 1995; Crombag et al., 2002). All rats were injected unilaterally with the FG tracer into the accumbens shell between the training and extinction phases and were tested for reinstatement 23-34 d after FG injections. Rats in the Control and Renewal groups were matched for their heroin intake and number of active lever presses during training and extinction, and injections of FG into left or right hemisphere were counterbalanced. At the end of the test session, rats were anesthetized, perfused with PBS and 4\% paraformaldehyde, and their brains were removed for subsequent immunohistochemistry.

Statistical analyses. Data were analyzed with ANOVAs or ANCOVAs using the statistical program SPSS (GLM procedure). Significant main

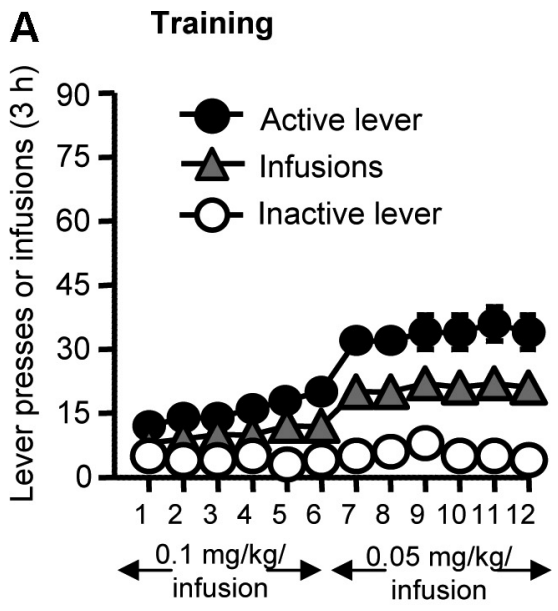

Training session

\section{B Extinction}

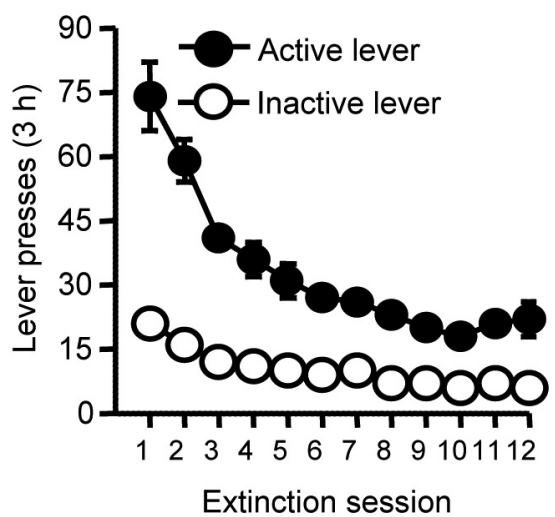

Figure 1. Heroin self-administration training and extinction of drug-reinforced responding. $A$, Mean \pm SEM number of infusions and active and inactive lever responses during the $12 \mathrm{~d}$ of heroin self-administration training (total $n=62$ ). $\boldsymbol{B}$, Mean \pm SEM number of presses on the active lever and inactive lever during the first 12 extinction sessions conducted in the absence of heroin in a different (extinction) context.

effects and interaction effects $(p<0.05)$ were followed by post hoc tests (Fisher PLSD). We used inactive lever presses, a potential measure of response generalization and/or nondirected activity (Shalev et al., 2002), as a covariate in Experiment 1 and Experiment 2 because contextinduced reinstatement had a modest effect on inactive lever pressing (means of 3.3-7.2 presses/3 h versus 2.0-5.6 presses/ $3 \mathrm{~h}$ in Contexts A and $\mathrm{B}$, respectively). Because our multifactorial ANOVAs or ANCOVAs yielded multiple main and interaction effects, we only report significant effects that are critical for data interpretation. Additionally, for clarity, post hoc analyses are indicated by asterisks in the figures but are not described in the Results section.

\section{Results}

\section{Training and extinction}

Figure $1 A$ shows mean \pm SEM number of heroin infusions and presses on the active and inactive levers for all rats. The rats demonstrated reliable heroin self-administration, as indicated by the increase in lever presses when the heroin dose was decreased from 0.1 to $0.05 \mathrm{mg} / \mathrm{kg} /$ infusion on training day $7(p<0.01)$. Figure $1 B$ shows the mean \pm SEM number of lever presses on the previously active and inactive levers during the first 12 extinction sessions. As expected, during the extinction phase, response rates decreased over time as evidenced by a main effect of training day $(p<0.01)$. 
A

\section{$\underline{\text { Contralateral injections }}$}

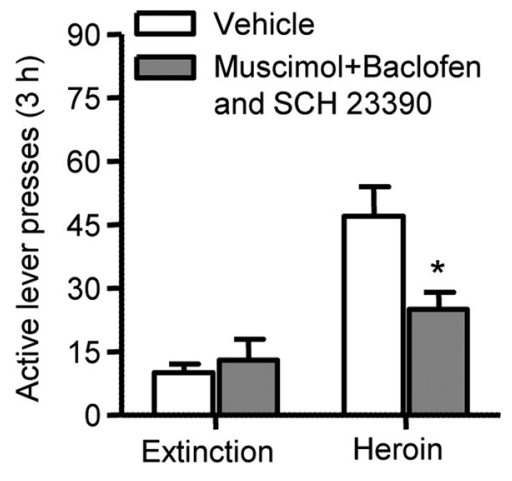

Test context

\section{Reinstatement}

Ipsilateral injections

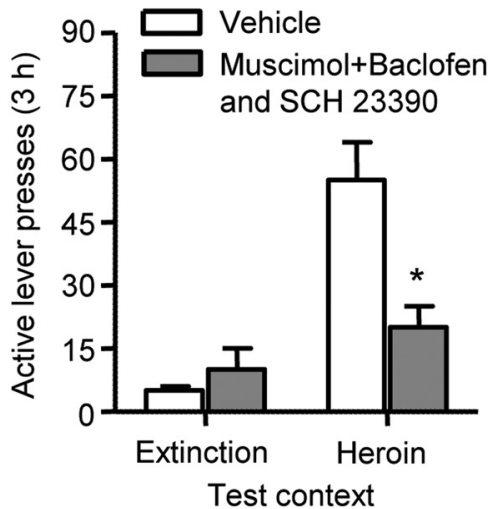

B

Cannula placements and representative pictures

\section{$\underline{\text { Contralateral injections }}$}
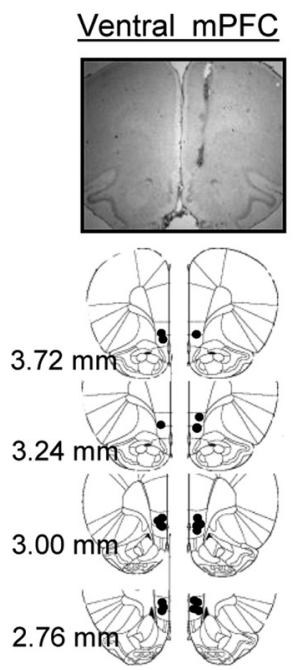

Accumbens shell
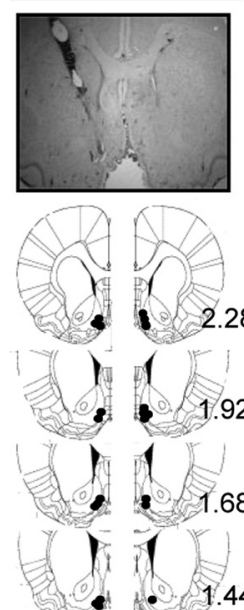

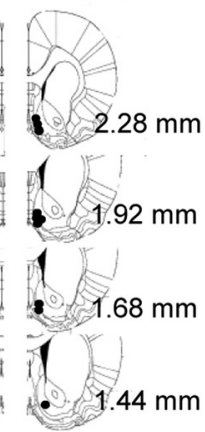

$\underline{\text { Ipsilateral injections }}$

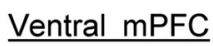

Accumbens shell
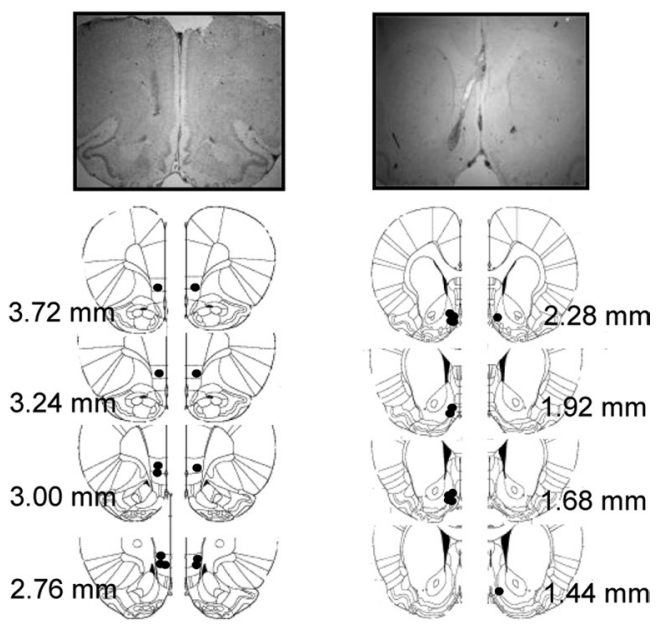

Figure 2. Effect of unilateral muscimol + baclofen injection into ventral mPFC combined with either contralateral or ipsilateral SCH 23390 injection into medial accumbens shell on contextinduced reinstatement. $\boldsymbol{A}$, Reinstatement. Shown are mean \pm SEM number of presses on the active lever after unilateral injection of muscimol + baclofen into ventral $\mathrm{mPFC}$ and contralateral (left, $n=11$ per group) or ipsilateral (right, $n=6$ per group) injection of SCH 23390 into medial accumbens shell before exposure to the Heroin context or the Extinction context. $\boldsymbol{B}$, Cannula placements and representative pictures. Approximate placements ( $\mathrm{mm}$ from bregma) of the injector tips for ventral mPFC and contralateral (left) or ipsilateral (right) medial accumbens shell (Paxinos and Watson, 2005) and representative photomicrographs of cannula placements are shown. Because implantation of cannulas into the left or right hemisphere was counterbalanced, injector tip placements are depicted in both hemispheres. ${ }^{*} p<0.01$, different from the Vehicle condition.

Unilateral muscimol + baclofen injection into ventral mPFC and contralateral or ipsilateral SCH 23390 injection into accumbens shell decreased context-induced reinstatement Unilateral muscimol + baclofen injection into ventral mPFC combined with either contralateral or ipsilateral SCH 23390 injection into accumbens shell decreased context-induced reinstatement of heroin seeking (Fig. 2). Data were analyzed by repeated measures ANCOVA (inactive lever presses as a covariate) using the between-subjects factors of Hemisphere (Ipsilateral or Contralateral) and Drug (Vehicle or Muscimol + baclofen and SCH 23390) and the within-subjects factor of Test Context [Heroin (A) or Extinction (B)]. The analyses demonstrated significant effects of Test Context $\left(F_{(1,28)}=15.3, p<0.01\right)$, Drug $\left(F_{(1,28)}=7.0, p<0.05\right)$, and Drug $\times$ Test Context $\left(F_{(1,28)}=26.0, p<0.01\right)$; no significant effects were found for Hemisphere or interactions between Hemisphere and the other factors $(p>0.05)$.
Muscimol + baclofen ventral mPFC injection combined with SCH 23390 injection into either the ipsilateral or contralateral accumbens shell had no effect on high-rate food-reinforced responding (mean \pm SEM number of active lever presses per 30 min were $243 \pm 44$ for the vehicle condition and $288 \pm 87$ and $226 \pm 48$ for the ipsilateral and contralateral drug injections, respectively, $p>0.1$ ). These data indicate that the effects of ipsilateral or contralateral drug injections on context-induced reinstatement of lever responding are not due to motor deficits.

Unilateral muscimol + baclofen injection into ventral mPFC or unilateral SCH 23390 injection into accumbens shell had no effect on context-induced reinstatement

Neither unilateral muscimol + baclofen injection into ventral mPFC nor unilateral SCH 23390 injection into accumbens shell decreased context-induced reinstatement (Fig. 3). The ANCOVA analysis (inactive lever presses as a covariate), which included the 


\section{Unilateral injections}

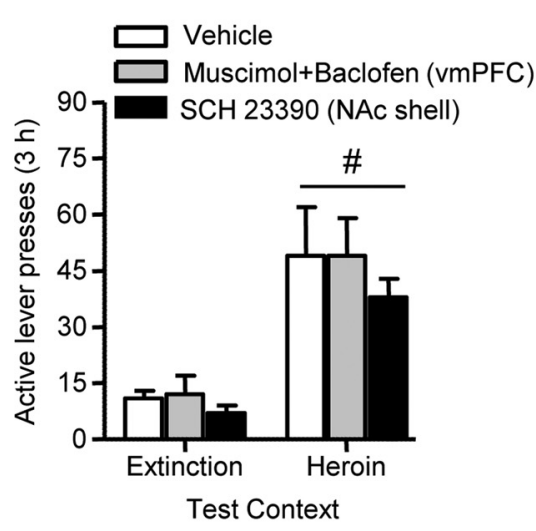

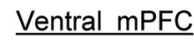
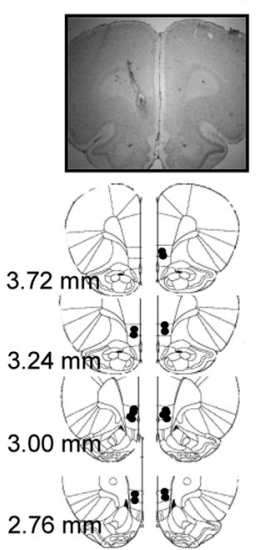

Figure 3. Effect of unilateral muscimol + baclofen injection into ventral mPFC or unilateral SCH 23390 injection into medial accumbens shell on context-induced reinstatement. Left, Mean \pm SEM number of presses on the active lever after either unilateral injection of muscimol + baclofen into ventral mPFC or unilateral injection of SCH 23390 into medial accumbens shell before exposure to the Heroin context or the Extinction context. Right, Cannula placements (see Fig. 2 legend for details). ${ }^{\#} p<0.01$, different from the Extinction context, $n=6-7$ per group.

between-subjects factor of Drug (Vehicle, Muscimol + baclofen, or SCH 23390) and the within-subjects factor of Test Context [Heroin (A) or Extinction (B)], demonstrated a significant effect of Test Context $\left(F_{(1,15)}=10.5, p<0.01\right)$; there were no effects of Drug or Drug $\times$ Test Context.

\section{Colocalization of Fos and FG, after unilateral FG injection into accumbens shell, in ipsilateral and contralateral ventral mPFC after a test for context-induced reinstatement}

Exposure to the Heroin context (Renewal group) reinstated active lever responding after extinction, as indicated by a significant interaction between Group (Control versus Renewal) and Lever $\left(F_{(1,6)}=16.2, p<0.01\right)$ (Fig. $\left.4 A\right)$. FG injections into medial accumbens shell resulted in reliable FG labeling in ventral $\mathrm{mPFC}$ and, confirming previous reports (Sesack et al., 1989; Vertes, 2004), stronger labeling in the ipsilateral hemisphere than in the contralateral hemisphere $\left(F_{(1,6)}=65.2, p<0.01\right)$ (Fig. $4 B$ ). There was no difference between the Control and Renewal groups in the number of FG-labeled neurons in both ipsilateral $(p>0.1)$ and contralateral $(p>0.1)$ ventral mPFC. Contextinduced reinstatement of heroin seeking was associated with a similar induction of Fos-IR nuclei in the ipsilateral and contralateral ventral mPFC (Fig. 4C), as indicated by a significant effect of Group $\left(F_{(1,6)}=54.7, p<0.01\right)$ but not Hemisphere or an interaction between Group and Hemisphere. After accumbens shell FG injections, significantly more Fos-FG double-labeled neurons were observed in ventral $\mathrm{mPFC}$ rats in the Renewal group than in the Control group $\left(F_{(1,6)}=18.0, p<0.01\right)$ (Fig. $\left.4 D\right)$. Within the Renewal group, there were no significant differences in the proportion of FG-Fos double-labeled neurons in ipsilateral versus contralateral ventral mPFC (Fig. $4 D$ ), indicating that both the dense ipsilateral project and the sparse contralateral projection from ventral mPFC to accumbens shell are activated during the test for context-induced reinstatement. This finding is supported by subsequent correlation analyses (using Pearson product-moment correlation coefficient, Pearson's $r$ ) between active lever presses during testing and either the number of FG-Fos double-labeled cells or the percentage of double-labeled cells [ (number of FG-Fos double-labeled cells/

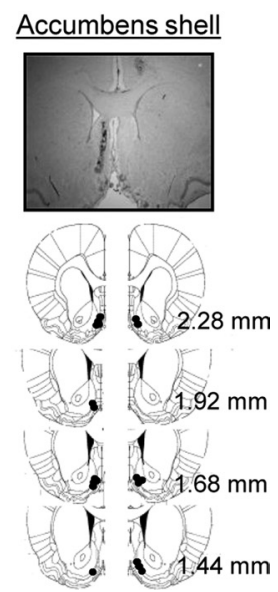

number of total FG cells $) \times 100$ ] in the Renewal group $(n=4)$. This analysis revealed high correlations between lever presses and each of the other two variables for both the ipsilateral projection $(r=0.99, p=0.008$ and $r=0.60, p=$ 0.396 for number of FG-Fos doublelabeled cells and percentage of doublelabeled cells, respectively) and the contralateral projection $(r=0.66, p=$ 0.352 and $r=0.98, p=0.013$, respectively). Finally, the pattern of immunohistochemical results obtained using the goat anti-c-Fos antibody for FG-IR, Fos-IR, and Fos +FG double-labeled cells (Table 1) were qualitatively similar to those obtained with the rabbit anti-cFos antibody (Fig. 4B-D). However, as mentioned in the Materials and Methods section, the absolute number of Fos-IR cells was significantly lower in the double-labeling assay using the goat anti-c-Fos antibody (Table 1) than in the double-labeling assay using the rabbit c-Fos antibody (Fig. 4C).

\section{Discussion}

We used an ABA renewal procedure (Bouton and Bolles, 1979; Bouton and Swartzentruber, 1991; Crombag and Shaham, 2002) to study the role of glutamatergic projections from ventral mPFC to accumbens shell in context-induced reinstatement of heroin seeking. We found that muscimol + baclofen injections into ventral mPFC combined with SCH 23390 injections into either contralateral or ipsilateral accumbens shell decreased context-induced reinstatement. In contrast, unilateral ventral mPFC muscimol + baclofen injections or unilateral accumbens shell SCH 23390 injections were ineffective. Using the retrograde tracer FG and the neuronal activity marker c-Fos, we found that both ipsilateral and contralateral ventral $\mathrm{mPFC}$ neurons that project to accumbens shell are activated during context-induced reinstatement of heroin seeking. We propose that an interaction between glutamatergic projections from ventral mPFC to accumbens shell and local dopamine $\mathrm{D}_{1}$ postsynaptic receptors contributes to context-induced reinstatement of heroin seeking.

It is unlikely that the effect of either contralateral or ipsilateral drug injections on context-induced reinstatement is due to diffusion into nearby brain sites or motor deficits. We previously found that SCH 23390 injections into accumbens core or muscimol + baclofen injections into dorsal mPFC had no effect on context-induced reinstatement (Bossert et al., 2007, 2011). Additionally, neither contralateral nor ipsilateral combined injections of muscimol + baclofen plus SCH 23390 decreased high-rate food-reinforced responding.

\section{Similar effects of ipsilateral and contralateral drug injections on context-induced reinstatement}

The main question arising from the present data is how to interpret the similar inhibitory effects of ipsilateral and contralateral pharmacological manipulations on context-induced reinstatement. The classic interpretation of asymmetrical disconnection studies is based on the premise that learned behaviors can be maintained by an intact single hemisphere and that projections are primarily ipsilateral (Gaffan et al., 1993; Setlow et al., 2002). However, in our study we found that the ipsilateral manipu- 
lation also inhibited context-induced reinstatement of heroin seeking. The similar effect of the ipsilateral and contralateral manipulations on contextinduced reinstatement might be due to the effect of muscimol + baclofen on interhemispheric mPFC activity of callosal neurons (Ferino et al., 1987; Carr and Sesack, 1998; Lupinsky et al., 2010) or local intrahemispheric mPFC connectivity (Goldman-Rakic, 1999). However, these possibilities are unlikely because there was no effect of unilateral mPFC muscimol + baclofen injections on reinstatement.

Another interpretation of the similar effect of ipsilateral and contralateral drug injections on context-induced reinstatement is that this behavior relies on activation of both dense ipsilateral projections and sparse contralateral mPFC-accumbens projections (Sesack et al., 1989; Vertes, 2004). Support for this hypothesis is provided by our Fos-FG double-labeling data, demonstrating that exposure to the heroin context activates both ipsilateral and contralateral ventral $\mathrm{mPFC}$ projections to accumbens shell. However, an issue to consider is that while the proportion of FG-positive neurons that were Fospositive was similar in the ipsilateral and contralateral projections, the total number of FG-Fos double-labeled neurons was higher in the ipsilateral than in the contralateral hemisphere.

How can we reconcile the difference in the number of context-activated neurons in ipsilateral versus contralateral ventral mPFC-accumbens shell projections with the similar behavioral effects of the ipsilateral and contralateral drug injections? Results from our study with the novel Daun02 selective inactivation method (Koya et al., 2009b) may be relevant. We found that inactivation of a small minority of context-sensitive ventral mPFC Fosactivated neurons mimicked the effect on context-induced reinstatement of muscimol + baclofen inactivation of the entire structure (Bossert et al., 2011). These results suggest that only a small minority of context-activated mPFC neurons mediate context-induced reinstatement. We speculate that this putative context-encoding mPFC "neuronal ensemble" is comprised of neurons that project to both ipsilateral accumbens shell and contralateral accumbens shell. In agreement with this idea, there is evidence that single cortical neurons send axon collaterals to the ipsilateral and contralateral striatum (Wilson, 1986; Ferino et al., 1987). It is tempting to speculate that the putative context-encoding ventral mPFC neural ensemble includes these accumbens shell projecting neurons.

However, while we argue that that both ipsilateral and contralateral ventral $\mathrm{mPFC}$-accumbens projections contribute to
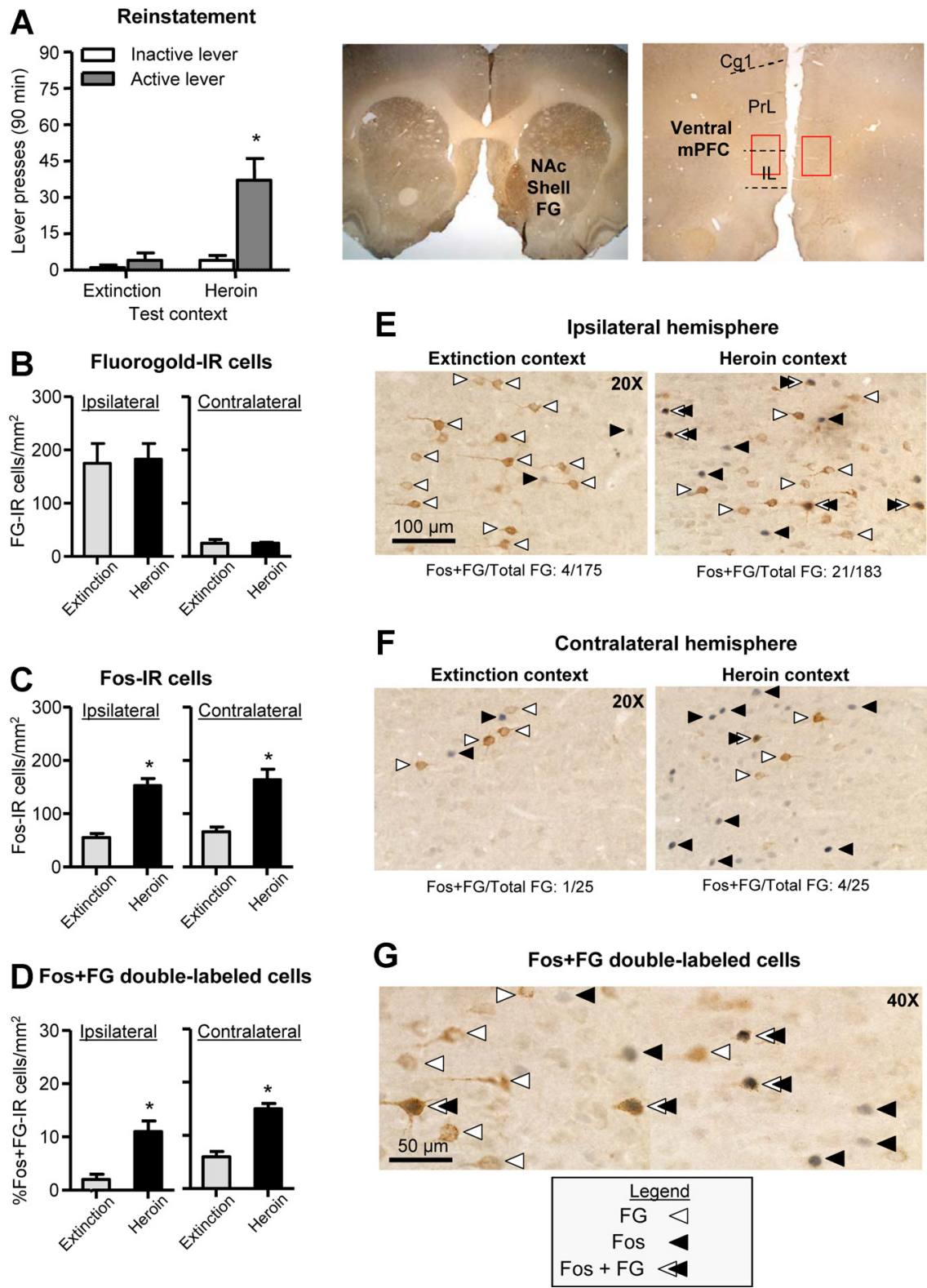

Figure 4. Unilateral injection of FG into accumbens shell and colocalization of FG with Fos in ventral mPFC after a context-induced reinstatement test. $\boldsymbol{A}$, Reinstatement Test (left), Total number of active lever and inactive lever presses in rats tested in the Extinction (Control A-B-B) or the Heroin (Renewal A-B-A) context. ${ }^{*} p<0.05$, different from the Extinction context, $n=4$ per group. FG injection site (right), Representative photomicrograph of unilateral FG injection into accumbens shell (left, $5 \times$ ) and FG labeling in $\mathrm{mPFC}$ (right, $5 \times$ ). NAc, nucleus accumbens; Cg1, anterior cingulate; Prl, prelimbic; IL, infralimbic. Red squares indicate area of FG and Fos quantification. $\boldsymbol{B}$, FG-IR cells: Number of FG-IR cells per $\mathrm{mm}^{2}$ in ipsilateral and contralateral ventral mPFC of rats tested in the Extinction or Heroin context. ${ }^{\#} p<0.01$, different from contralateral, $n=4$ per group. C, Fos-IR cells: Number of Fos-IR nuclei per $\mathrm{mm}^{2}$ in ipsilateral and contralateral ventral $\mathrm{mPFC}$ of rats tested in the Extinction context or the Heroin context. ${ }^{*} p<0.01$, different from the Extinction context. $D$, Fos $+\mathrm{FG}$ double-labeled cells: Percentage of Fos + FG-IR cells in the ipsilateral and contralateral ventral mPFC of rats tested in the Extinction context or Heroin context. ${ }^{*} p<0.01$, different from Extinction context. $\boldsymbol{E}, \boldsymbol{F}$, Representative photomicrographs of Fos and FG cells in ipsilateral $(\boldsymbol{E})$ and contralateral $(\boldsymbol{F})$ ventral mPFC of rats tested in the Extinction or Heroin context $(20 \times)$. G, Representative photomicrograph of ventral $\mathrm{mPFC}$ of a rat tested in the Heroin context ( $40 \times$ ). White arrows indicate FG-positive cells, black arrows indicate Fos-positive nuclei, and white/black arrows indicate Fos + FG double-labeled cells. Scale bars: (in $\boldsymbol{E}), \boldsymbol{E}, \boldsymbol{F}, 100 \mu \mathrm{m} ; \boldsymbol{G}, 50 \mu \mathrm{m}$.

Table 1. Quantification of FG-IR, Fos-IR, and percentage of double-labeled Fos + FG cells using goat anti-c-Fos primary antibody in the Control (ABB) and Renewal (ABA) groups (mean \pm SEM; $n=4 /$ group)

\begin{tabular}{|c|c|c|c|c|}
\hline & \multicolumn{2}{|c|}{ Ipsilateral hemisphere } & \multicolumn{2}{|c|}{ Contralateral hemisphere } \\
\hline & Control (ABB) & Renewal (ABA) & Control (ABB) & Renewal (ABA) \\
\hline $\mathrm{FG}-\mathrm{IR}\left(\mathrm{mm}^{2}\right)$ & $115.6 \pm 33.4$ & $123.3 \pm 12.4$ & $21.8 \pm 8.9$ & $18.4 \pm 2.4$ \\
\hline Fos-IR $\left(\mathrm{mm}^{2}\right)$ & $8.6 \pm 3.4$ & $55.6 \pm 4.9$ & $8.4 \pm 2.7$ & $50.0 \pm 2.9$ \\
\hline Fos + FG cells (\% FG) & $1.0 \pm 0.3$ & $7.4 \pm 0.8$ & $2.8 \pm 1.2$ & $13.0 \pm 0.8$ \\
\hline
\end{tabular}


context-induced reinstatement, there are alternative interpretations of our behavioral data. One is that the ipsilateral and contralateral manipulations merely interfere with behavior during testing to a greater extent than a single unilateral manipulation, independent of the pathway involved. This nonspecific behavioral disruption account of the data is unlikely, however, because neither ipsilateral nor contralateral drug injections decreased high-rate food-reinforced responding.

Another alternative interpretation of our data is that the similar effects of contralateral and ipsilateral manipulations are due to the disruption of communication between ventral mPFC and accumbens shell through an additional brain region via both ipsilateral and contralateral projections. One potential brain region is the ventral tegmental area (VTA). The VTA receives ipsilateral and contralateral glutamatergic projections from mPFC (Beckstead, 1979; Sesack et al., 1989), and local inhibition of glutamate transmission attenuates context-induced reinstatement of heroin seeking (Bossert et al., 2004). Additionally, stimulation of mPFC in one hemisphere increases dopamine release in both contralateral and ipsilateral accumbens; this effect is reversed by blockade of VTA glutamate receptors (Karreman and Moghaddam, 1996; You et al., 1998). Another potential brain region is the ventral subiculum. Inactivation of ventral subiculum blocks contextinduced reinstatement of both heroin (J. M. Bossert, unpublished data) and cocaine (Lasseter et al., 2010) seeking. The ventral subiculum sends glutamatergic projections to both accumbens shell (some of them contralateral) and $\mathrm{mPFC}$ and receives indirect ipsilateral and contralateral glutamatergic projections from mPFC via the entorhinal cortex (Groenewegen et al., 1987; Sesack et al., 1989; Jay and Witter, 1991; Insausti et al., 1997; Thierry et al., 2000). Additionally, there is evidence that accumbens synaptic transmission and certain accumbens-mediated behaviors are controlled by converging projections from ventral subiculum and mPFC (O’Donnell, 2003; Floresco, 2007; Grace et al., 2007). Thus, our ipsilateral manipulation could potentially disrupt communication between ventral $\mathrm{mPFC}$ and contralateral accumbens shell, via interhemispheric projections to VTA and/or ventral subiculum.

Finally, our data on the similar effects of ipsilateral and contralateral manipulations on context-induced reinstatement are in agreement with results from studies in which asymmetrical disconnection procedures were used to assess the role of $\mathrm{mPFC}$ projections to either accumbens or amygdala or amygdala projections to accumbens in reinstatement of drug seeking (Fuchs et al., 2007; Peters et al., 2008; Chaudhri et al., 2010; Lasseter et al., 2011). We suggest that, as in our study, the effects of the ipsilateral manipulations on reinstatement of drug seeking in these studies were due to interruption of interhemispheric communication via contralateral projections.

\section{Different mPFC-accumbens projections control heroin versus cocaine seeking}

An influential neuroanatomical framework of drug relapse is that dorsal mPFC (prelimbic, cingulate subregions)-core pathway promotes drug seeking while ventral $\mathrm{mPFC}$ (infralimbic region)accumbens shell inhibits drug seeking after extinction (Peters et al., 2009). The presumed excitatory role of dorsal mPFC-accumbens core projection in drug relapse is primarily based on results from studies in which cocaine-trained rats were exposed to cocaine priming (McFarland and Kalivas, 2001), discrete cues (McLaughlin and See, 2003; Fuchs et al., 2004), contextual cues (Fuchs et al., 2005, 2008), or footshock stress (Capriles et al., 2003; McFarland et al., 2004; but see Anderson et al., 2003, 2006) for a selective role of accumbens shell dopamine in cocaine priming-induced reinstatement. The inhibitory role of ventral mPFC-accumbens shell projection is based on results demonstrating that reversible inactivation of ventral mPFC or ipsilateral or contralateral inactivation of its projection to accumbens shell reinstates cocaine seeking or potentiates spontaneous recovery after extinction (Peters et al., 2007; Peters et al., 2008). There is also recent evidence for a role of ventral mPFC and accumbens shell in inhibition of alcoholic beer seeking after extinction (Marchant et al., 2010; Millan et al., 2010, 2011) and suppression of nonreinforced responding during a discrimination task in sucrose-trained rats (Ghazizadeh et al., 2012).

Our data on the role of ventral mPFC-accumbens shell projection in context-induced reinstatement of heroin seeking, as well as our previous data on the roles of accumbens shell but not core (Bossert et al., 2006a, 2007) and ventral but not dorsal mPFC (Bossert et al., 2011) in this reinstatement, suggest that the dichotomy of $\mathrm{mPFC}$-accumbens projections for inhibition versus promotion of drug relapse (Peters et al., 2009) does not apply to heroin. In support of this conclusion, Rogers et al. (2008) reported that inhibition of ventral mPFC neurons with muscimolbaclofen attenuates discrete cue- and heroin priming-induced reinstatement of heroin seeking; but see Van den Oever et al. (2008) and Schmidt et al. (2005) for different results.

\section{Concluding remarks}

We combined a variation of an established asymmetrical disconnection procedure with retrograde tracing and Fos immunohistochemistry to demonstrate that activation of the bilateral ventral mPFC projections to accumbens shell contributes to contextinduced reinstatement of heroin seeking via an interaction with local postsynaptic dopamine $\mathrm{D}_{1}$ receptors. Our present and previous findings suggest that while there are some similarities in the brain sites and circuits controlling reinstatement of heroin versus cocaine seeking (Alvarez-Jaimes et al., 2008; LaLumiere and Kalivas, 2008; Rogers et al., 2008), there are also some fundamental differences (Crombag et al., 2008; Badiani et al., 2011). These findings extend previous reports demonstrating that cocaineand heroin-taking behaviors are mediated by different mechanisms (Ettenberg et al., 1982; Mello and Negus, 1996; Celentano et al., 2009; Badiani et al., 2011) and have implications for future studies on mechanisms of drug relapse and relapse prevention across drug classes.

\section{References}

Alvarez-Jaimes L, Polis I, Parsons LH (2008) Attenuation of cue-induced heroin-seeking behavior by cannabinoid CB1 antagonist infusions into the nucleus accumbens core and prefrontal cortex, but not basolateral amygdala. Neuropsychopharmacology 33:2483-2493.

Anderson SM, Bari AA, Pierce RC (2003) Administration of the D1-like dopamine receptor antagonist SCH-23390 into the medial nucleus accumbens shell attenuates cocaine priming-induced reinstatement of drug-seeking behavior in rats. Psychopharmacology 168:132-138.

Anderson SM, Schmidt HD, Pierce RC (2006) Administration of the D2 dopamine receptor antagonist sulpiride into the shell, but not the core, of the nucleus accumbens attenuates cocaine priming-induced reinstatement of drug seeking. Neuropsychopharmacology 31:1452-1461.

Badiani A, Belin D, Epstein D, Calu D, Shaham Y (2011) Opiate versus psychostimulant addiction: the differences do matter. Nat Rev Neurosci 12:685-700.

Beckstead RM (1979) An autoradiographic examination of corticocortical and subcortical projections of the mediodorsal-projection (prefrontal) cortex in the rat. J Comp Neurol 184:43-62.

Belin D, Everitt BJ (2008) Cocaine seeking habits depend upon dopaminedependent serial connectivity linking the ventral with the dorsal striatum. Neuron 57:432-441. 
Bossert JM, Liu SY, Lu L, Shaham Y (2004) A role of ventral tegmental area glutamate in contextual cue-induced relapse to heroin seeking. J Neurosci 24:10726-10730.

Bossert JM, Gray SM, Lu L, Shaham Y (2006a) Activation of group II metabotropic glutamate receptors in the nucleus accumbens shell attenuates context-induced relapse to heroin seeking. Neuropsychopharmacology 31:2197-2209.

Bossert JM, Poles GC, Sheffler-Collins SI, Ghitza UE (2006b) The mGluR2/3 agonist LY379268 attenuates context- and discrete cue-induced reinstatement of sucrose seeking but not sucrose self-administration in rats. Behav Brain Res 173:148-152.

Bossert JM, Poles GC, Wihbey KA, Koya E, Shaham Y (2007) Differential effects of blockade of dopamine D1-family receptors in nucleus accumbens core or shell on reinstatement of heroin seeking induced by contextual and discrete cues. J Neurosci 27:12655-12663.

Bossert JM, Wihbey KA, Pickens CL, Nair SG, Shaham Y (2009) Role of dopamine $\mathrm{D}(1)$-family receptors in dorsolateral striatum in contextinduced reinstatement of heroin seeking in rats. Psychopharmacology 206:51-60.

Bossert JM, Stern AL, Theberge FR, Cifani C, Koya E, Hope BT, Shaham Y (2011) Ventral medial prefrontal cortex neuronal ensembles mediate context-induced relapse to heroin. Nat Neurosci 14:420-422.

Bouton ME, Bolles RC (1979) Role of conditioned contextual stimuli in reinstatement of extinguished fear. J Exp Psychol Anim Behav Process 5:368-378.

Bouton ME, Swartzentruber D (1991) Sources of relapse after extinction in Pavlovian and instrumental learning. Clin Psychol Rev 11:123-140.

Capriles N, Rodaros D, Sorge RE, Stewart J (2003) A role for the prefrontal cortex in stress- and cocaine-induced reinstatement of cocaine seeking in rats. Psychopharmacology (Berl) 168:66-74.

Carr DB, Sesack SR (1998) Callosal terminals in the rat prefrontal cortex: synaptic targets and association with GABA-immunoreactive structures. Synapse 29:193-205.

Celentano M, Caprioli D, Dipasquale P, Cardillo V, Nencini P, Gaetani S, Badiani A (2009) Drug context differently regulates cocaine versus heroin self-administration and cocaine- versus heroin-induced Fos mRNA expression in the rat. Psychopharmacology 204:349-360.

Chaudhri N, Sahuque LL, Woods C, Gill TM, Janak PH (2010) Functionally disconnecting the basolateral amygdala and nucleus accumbens core: effects on context-induced renewal of alcohol seeking in rats. Soc Neurosci Abstr 36:163.24.

Crombag HS, Shaham Y (2002) Renewal of drug seeking by contextual cues after prolonged extinction in rats. Behav Neurosci 116:169-173.

Crombag HS, Jedynak JP, Redmond K, Robinson TE, Hope BT (2002) Locomotor sensitization to cocaine is associated with increased Fos expression in the accumbens, but not in the caudate. Behav Brain Res 136:455-462.

Crombag HS, Bossert JM, Koya E, Shaham Y (2008) Context-induced relapse to drug seeking: a review. Philos Trans R Soc Lond B Biol Sci 363:3233-3243.

Curran T, Morgan JI (1995) Fos: an immediate-early transcription factor in neurons. J Neurobiol 26:403-412.

Diergaarde L, de Vries W, Raasø H, Schoffelmeer AN, De Vries TJ (2008) Contextual renewal of nicotine seeking in rats and its suppression by the cannabinoid-1 receptor antagonist Rimonabant (SR141716A). Neuropharmacology 55:712-716.

Divac I, Mogensen J (1990) Long-term retrograde labelling of neurons. Brain Res 524:339-341.

Ettenberg A, Pettit HO, Bloom FE, Koob GF (1982) Heroin and cocaine intravenous self-administration in rats: mediation by separate neural systems. Psychopharmacology 78:204-209.

Everitt BJ, Morris KA, O’Brien A, Robbins TW (1991) The basolateral amygdala-ventral striatal system and conditioned place preference: further evidence of limbic-striatal interactions underlying reward-related processes. Neuroscience 42:1-18.

Ferino F, Thierry AM, Saffroy M, Glowinski J (1987) Interhemispheric and subcortical collaterals of medial prefrontal cortical neurons in the rat. Brain Res 417:257-266.

Floresco SB (2007) Dopaminergic regulation of limbic-striatal interplay. J Psychiatry Neurosci 32:400-411.

Floresco SB, Seamans JK, Phillips AG (1997) Selective roles for hippocampal, prefrontal cortical, and ventral striatal circuits in radial-arm maze tasks with or without a delay. J Neurosci 17:1880-1890.
Fuchs RA, Evans KA, Parker MC, See RE (2004) Differential involvement of the core and shell subregions of the nucleus accumbens in conditioned cue-induced reinstatement of cocaine seeking in rats. Psychopharmacology 176:459-465.

Fuchs RA, Evans KA, Ledford CC, Parker MP, Case JM, Mehta RH, See RE (2005) The role of the dorsomedial prefrontal cortex, basolateral amygdala, and dorsal hippocampus in contextual reinstatement of cocaine seeking in rats. Neuropsychopharmacology 30:296-309.

Fuchs RA, Eaddy JL, Su ZI, Bell GH (2007) Interactions of the basolateral amygdala with the dorsal hippocampus and dorsomedial prefrontal cortex regulate drug context-induced reinstatement of cocaine-seeking in rats. Eur J Neurosci 26:487-498.

Fuchs RA, Ramirez DR, Bell GH (2008) Nucleus accumbens shell and core involvement in drug context-induced reinstatement of cocaine seeking in rats. Psychopharmacology 200:545-556.

Gaffan D, Murray EA, Fabre-Thorpe M (1993) Interaction of the amygdala with the frontal lobe in reward memory. Eur J Neurosci 5:968-975.

Ghazizadeh A, Ambroggi F, Odean N, Fields HL (2012) Prefrontal cortex mediates extinction of responding by two distinct neural mechanisms in accumbens shell. J Neurosci 32:726-737.

Goldman-Rakic PS (1999) The physiological approach: functional architecture of working memory and disordered cognition in schizophrenia. Biol Psychiatry 46:650-661.

Grace AA, Floresco SB, Goto Y, Lodge DJ (2007) Regulation of firing of dopaminergic neurons and control of goal-directed behaviors. Trends Neursoci 30:220-227.

Groenewegen HJ, Vermeulen-Van der Zee E, te Kortschot A, Witter MP (1987) Organization of the projections from the subiculum to the ventral striatum in the rat. A study using anterograde transport of Phaseolus vulgaris leucoagglutinin. Neuroscience 23:103-120.

Groenewegen HJ, Wright CI, Beijer AV, Voorn P (1999) Convergence and segregation of ventral striatal inputs and outputs. Ann N Y Acad Sci 877:49-63.

Hamlin AS, Newby J, McNally GP (2007) The neural correlates and role of D1 dopamine receptors in renewal of extinguished alcohol-seeking. Neuroscience 146:525-536.

Ikemoto S, Qin M, Liu ZH (2005) The functional divide for primary reinforcement of D-amphetamine lies between the medial and lateral ventral striatum: is the division of the accumbens core, shell, and olfactory tubercle valid? J Neurosci 25:5061-5065.

Insausti R, Herrero MT, Witter MP (1997) Entorhinal cortex of the rat: cytoarchitectonic subdivisions and the origin and distribution of cortical efferents. Hippocampus 7:146-183.

Jay TM, Witter MP (1991) Distribution of hippocampal CA1 and subicular efferents in the prefrontal cortex of the rat studied by means of anterograde transport of Phaseolus vulgaris-leucoagglutinin. J Comp Neurol 313:574-586.

Karreman M, Moghaddam B (1996) The prefrontal cortex regulates the basal release of dopamine in the limbic striatum: an effect mediated by ventral tegmental area. J Neurochem 66:589-598.

Koya E, Uejima JL, Wihbey KA, Bossert JM, Hope BT, Shaham Y (2009a) Role of ventral medial prefrontal cortex in incubation of cocaine craving. Neuropharmacology 56 [Suppl 1]:177-185.

Koya E, Golden SA, Harvey BK, Guez-Barber DH, Berkow A, Simmons DE, Bossert JM, Nair SG, Uejima JL, Marin MT, Mitchell TB, Farquhar D, Ghosh SC, Mattson BJ, Hope BT (2009b) Targeted disruption of cocaine-activated nucleus accumbens neurons prevents context-specific sensitization. Nat Neurosci 12:1069-1073.

LaLumiere RT, Kalivas PW (2008) Glutamate release in the nucleus accumbens core is necessary for heroin seeking. J Neurosci 28:3170-3177.

Lasseter HC, Xie X, Ramirez DR, Fuchs RA (2010) Sub-region specific contribution of the ventral hippocampus to drug context-induced reinstatement of cocaine-seeking behavior in rats. Neuroscience 171:830-839.

Lasseter HC, Wells AM, Xie X, Fuchs RA (2011) Interaction of the basolateral amygdala and orbitofrontal cortex is critical for drug context-induced reinstatement of cocaine-seeking behavior in rats. Neuropsychopharmacology 36:711-720.

Lu L, Grimm JW, Dempsey J, Shaham Y (2004) Cocaine seeking over extended withdrawal periods in rats: different time courses of responding induced by cocaine cues versus cocaine priming over the first 6 months. Psychopharmacology 176:101-108.

Lupinsky D, Moquin L, Gratton A (2010) Interhemispheric regulation of 
the medial prefrontal cortical glutamate stress response in rats. J Neurosci 30:7624-7633.

Marchant NJ, Furlong TM, McNally GP (2010) Medial dorsal hypothalamus mediates the inhibition of reward seeking after extinction. J Neurosci 30:14102-14115.

McFarland K, Kalivas PW (2001) The circuitry mediating cocaine-induced reinstatement of drug-seeking behavior. J Neurosci 21:8655-8663.

McFarland K, Davidge SB, Lapish CC, Kalivas PW (2004) Limbic and motor circuitry underlying footshock-induced reinstatement of cocaine-seeking behavior. J Neurosci 24:1551-1560.

McLaughlin J, See RE (2003) Selective inactivation of the dorsomedial prefrontal cortex and the basolateral amygdala attenuates conditioned-cued reinstatement of extinguished cocaine-seeking behavior in rats. Psychopharmacology (Berl) 168:57-65.

Mello NK, Negus SS (1996) Preclinical evaluation of pharmacotherapies for treatment of cocaine and opioid abuse using drug self-administration procedures. Neuropsychopharmacology 14:375-424.

Millan EZ, Furlong TM, McNally GP (2010) Accumbens shell-hypothalamus interactions mediate extinction of alcohol seeking. J Neurosci 30:4626-4635.

Millan EZ, Marchant NJ, McNally GP (2011) Extinction of drug seeking. Behav Brain Res 217:454-462.

Miller CA, Marshall JF (2005) Altered Fos expression in neural pathways underlying cue-elicited drug seeking in the rat. Eur J Neurosci 21:1385-1393.

Morales M, Wang SD (2002) Differential composition of 5-hydroxytryptamine3 receptors synthesized in the rat CNS and peripheral nervous system. J Neurosci 22:6732-6741.

Morales M, Criado JR, Sanna PP, Henriksen SJ, Bloom FE (1998) Acute ethanol induces c-fos immunoreactivity in GABAergic neurons of the central nucleus of the amygdala. Brain Res 798:333-336.

Nair SG, Navarre BM, Cifani C, Pickens CL, Bossert JM, Shaham Y (2011) Role of dorsal medial prefrontal cortex dopamine D1-family receptors in relapse to high-fat food seeking induced by the anxiogenic drug yohimbine. Neuropsychopharmacology 36:497-510.

O'Brien CP, Childress AR, Mclellan AT, Ehrman R (1992) Classical conditioning in drug dependent humans. Ann N Y Acad Sci 654:400-415.

O’Donnell P (2003) Dopamine gating of forebrain neural ensembles. Eur J Neurosci 17:429-435.

Paxinos G, Watson C (2005) The rat brain in stereotaxic coordinates, Ed 5. Amsterdam: Elsevier Academic.

Peters J, Vallone J, Laurendi K, Kalivas PW (2007) Opposing roles for the ventral prefrontal cortex and the basolateral amygdala on the spontaneous recovery of cocaine-seeking in rats. Psychopharmacology (Berlin) 197:319-326.

Peters J, LaLumiere RT, Kalivas PW (2008) Infralimbic prefrontal cortex is responsible for inhibiting cocaine seeking in extinguished rats. J Neurosci 28:6046-6053.

Peters J, Kalivas PW, Quirk GJ (2009) Extinction circuits for fear and addiction overlap in prefrontal cortex. Learn Mem 16:279-288.

Rogers JL, Ghee S, See RE (2008) The neural circuitry underlying reinstate- ment of heroin-seeking behavior in an animal model of relapse. Neuroscience 151:579-588.

Sagar SM, Sharp FR, Curran T (1988) Expression of c-fos protein in brain: metabolic mapping at the cellular level. Science 240:1328-1331.

Schmidt ED, Voorn P, Binnekade R, Schoffelmeer AN, De Vries TJ (2005) Differential involvement of the prelimbic cortex and striatum in conditioned heroin and sucrose seeking following long-term extinction. Eur J Neurosci 22:2347-2356.

Schmued LC, Fallon JH (1986) Fluoro-Gold: a new fluorescent retrograde axonal tracer with numerous unique properties. Brain Res 377:147-154.

Sesack SR, Deutch AY, Roth RH, Bunney BS (1989) Topographical organization of the efferent projections of the medial prefrontal cortex in the rat: an anterograde tract-tracing study with Phaseolus vulgaris leucoagglutinin. J Comp Neurol 290:213-242.

Setlow B, Holland PC, Gallagher M (2002) Disconnection of the basolateral amygdala complex and nucleus accumbens impairs appetitive pavlovian second-order conditioned responses. Behav Neurosci 116:267-275.

Shalev U, Grimm JW, Shaham Y (2002) Neurobiology of relapse to heroin and cocaine seeking: a review. Pharmacol Rev 54:1-42.

Shalev U, Robarts P, Shaham Y, Morales M (2003) Selective induction of c-Fos immunoreactivity in the prelimbic cortex during reinstatement of heroin seeking induced by acute food deprivation in rats. Behav Brain Res 145:79-88.

Thierry AM, Gioanni Y, Dégénétais E, Glowinski J (2000) Hippocampoprefrontal cortex pathway: anatomical and electrophysiological characteristics. Hippocampus 10:411-419.

Van den Oever MC, Goriounova NA, Li KW, Van der Schors RC, Binnekade R, Schoffelmeer AN, Mansvelder HD, Smit AB, Spijker S, De Vries TJ (2008) Prefrontal cortex AMPA receptor plasticity is crucial for cueinduced relapse to heroin-seeking. Nat Neurosci 11:1053-1058.

Vertes RP (2004) Differential projections of the infralimbic and prelimbic cortex in the rat. Synapse 51:32-58.

Weiss F, Maldonado-Vlaar CS, Parsons LH, Kerr TM, Smith DL, Ben-Shahar O (2000) Control of cocaine-seeking behavior by drug-associated stimuli in rats: effects on recovery of extinguished operant-responding and extracellular dopamine levels in amygdala and nucleus accumbens. Proc Natl Acad Sci U S A 97:4321-4326.

Wikler A (1973) Dynamics of drug dependence. Implications of a conditioning theory for research and treatment. Arch Gen Psychiatry 28:611-616.

Wilson CJ (1986) Postsynaptic potentials evoked in spiny neostriatal projection neurons by stimulation of ipsilateral and contralateral neocortex. Brain Res 367:201-213.

Yamaguchi T, Wang HL, Li X, Ng TH, Morales M (2011) Mesocorticolimbic glutamatergic pathway. J Neurosci 31:8476-8490.

You ZB, Tzschentke TM, Brodin E, Wise RA (1998) Electrical stimulation of the prefrontal cortex increases cholecystokinin, glutamate, and dopamine release in the nucleus accumbens: an in vivo microdialysis study in freely moving rats. J Neurosci 18:6492-6500.

Zironi I, Burattini C, Aicardi G, Janak PH (2006) Context is a trigger for relapse to alcohol. Behav Brain Res 167:150-155. 